\title{
Mística e Teologia: Desafios contemporâneos e contribuições
}

Ceci Baptista Mariani

A palavra mística na atualidade refere-se a um conceito de difícil definição, é em geral utilizado de forma fluida e aparece muitas vezes entendido como sinônimo de esoterismo ou, simplesmente, como sinônimo de religião ${ }^{1}$. Há também quem utilize o conceito para falar de uma energia ou força interior que mobiliza o sujeito, ou como um sentimento, uma sensação ou uma emoção. Sentidos que tem, certamente, relação com o uso que fizeram dele os românticos, sentidos que emergem da valorização da experiência religiosa subjetiva, quando do processo operado pela reforma, de interiorização da religião.

Um melhor entendimento desse conceito e da contribuição que a mística pode oferecer à vivência e à reflexão sobre a experiência religiosa supõe, no entanto, entendemos a recuperação de elementos importantes que caracterizam a mística, presentes na história da utilização desse conceito no interior da tradição cristã, história que remonta ao século III.

Neste artigo, buscaremos refletir sobre a mística, procurando explicitar esses elementos e em seguida ponderar sobre sua relevância para a exigência atual de uma teologia que, diante dos tantos desafios colocados pela vida contemporânea, num mundo globalizado, deva se manter aberta, sobretudo ao diálogo com as outras religiões.

${ }^{1}$ Carlos Eduardo SELL e Franz Josef BRüSEKE, Mistica e Sociedade, p.17. 


\section{A palavra mística em seu uso original na tradição cristã}

A palavra mística, aplicada a uma certa maneira de conhecer Deus diretamente e de maneira quase experimental, segundo L. Bouyer, tem sua origem no uso original que encontra dentro da tradição cristã. Segundo esse autor, os empregos pré-cristãos mais antigos da palavra não têm esse sentido:
(...) Na religiosidade helenista, o "segredo", que é propri- amente "místico", não é o segredo de algum inefável co- nhecimento religioso, mas é o segredo de um rito em sua pura materialidade. $^{2}$

Para os Padres Gregos, a mística é, antes de tudo, a realidade divina que o Cristo nos traz, que o Evangelho nos revela, que dá sentido definitivo a toda a Escritura:
É místico, portanto, todo conhecimento das coisas divinas às quais se ascendem por Cristo, em seguida, por deriva- ção, estas coisas em si mesmas. Enfim, a palavra passa, sempre na mesma linha, pela realidade espiritual do culto "em Espírito e em Verdade", oposta à vacuidade de uma religião exterior que a vinda do Salvador não revivificou. ${ }^{3}$

Do contexto Bíblico, afirma Bouyer, a palavra mística passa ao contexto sacramental, em especial, ao eucarístico. O que se vê nos textos antigos, explicita ele, é o duplo cuidado de insistir sobre a realidade da Eucaristia que é o Cristo e todos os dons que dele não se separam (os sacramentos) e sobre o fato de que essa realidade é ainda, de certa maneira, velada. A última Ceia vai inspirar uma série de textos onde o sentido da palavra mística passa da idéia de compreensão das Escrituras à idéia de uma realidade sacramental ${ }^{4}$. Nestes textos, comenta o autor, os Padres da época constantiniana vão aplicar, pela primeira vez, a terminologia dos rituais pagãos aos ritos cristãos.

Nestes textos onde esta referência primeira à realidade sobrenatural do Cristo aparece ainda subjacente, mais onde uma primeira transferência deliberada à celebração do mistério cristão dos termos dos mistérios pagãos suplantados

\footnotetext{
${ }^{2}$ BOUYER, L., "MYSTIQUE” Essai sur l'histoire dúm mot. La Vie Spirituali, no.9 - 15 Maio 1949.

${ }^{3}$ Ibidem, p. 13.

${ }^{4}$ Cf. Ibidem, p. 13-14.
} 
por ele parece não estar excluída, o conjunto da liturgia eucarística é chamado "culto mistérico", "hierurgia mística". Esse é, com efeito, um traço marcante da terminologia litúrgica dos Padres da época constantiniana, o de aplicar pela primeira vez, aos ritos cristãos, as expressões emprestadas dos rituais pagãos. ${ }^{5}$

A palavra mística designa, então, sempre a mesma realidade central do cristianismo, seja sob o aspecto de revelação final do plano de Deus discernido através das Escrituras, elaborado através de toda a história humana; seja sob o aspecto do símbolo sacramental que contém, ele mesmo, o objeto desta revelação e que acaba por ele de se realizar em nós.

O terceiro sentido da palavra mística, ainda segundo o mesmo autor, sentido que não se desenvolve independentemente do uso da palavra no contexto exegético e litúrgico, mas que adquire o sentido espiritual de modo inefável de conhecimento experimental das coisas divinas, encontra-se em Dionísio Areopagita, e aqui devemos fazer um destaque.

\section{A Teologia Mística de Dionísio Areopagita}

Em seu pequeno tratado denominado Teologia Mística, de importância fundamental para todo o desenvolvimento do pensamento cristão, Dionísio Areopagita não só cria o termo "teologia mística", afirma Bernard McGinn, como dá expressão sistemática à visão dialética da relação entre Deus e o mundo que foi a fonte de sistemas mistico-especulativos por pelo menos mil anos ${ }^{6}$. A estrutura do sistema teológico de Dionísio, segundo esse autor, é a mais importante contribuição para a história da mística latina ${ }^{7}$.

Nesse tratado, que deve ser interpretado em relação ao conjunto de sua obra $^{8}$, "místicas" são revelações dos mistérios simples, absolutos e imutáveis

\footnotetext{
${ }^{5}$ Ibidem, p. 15.

${ }^{6}$ McGINN, Bernard. The Foundations of Mysticis : The Presence of God: A History of Western Christian Mysticism. New York, Crossroad, 2003, p. 158

${ }^{7}$ Cf. Ibidem, p. 161.

${ }^{8}$ No capítulo III de sua Teologia Mística, Dionísio explicita o lugar dessa última no conjunto de sua obra e indica que o silêncio místico é fruto de uma ascese e antes de chegar a ele é preciso considerar as muitas palavras e a presença de Deus em toda a criação: "No livro Dos nomes divinos (explicamos) como Deus é chamado bom, e como é chamado ser, vida, sabedoria e potência, e todas as denominações divinas. Na Teologia simbólica (tratamos) dos nomes transferíveis dos objetos sensíveis às coisas divinas, formas e figuras divinas, partes, instrumentos, lugares divinos, ornatos, iras, aflições, dores, cóleras, ebriedades, excessos, juramentos, imprecações, sonos, vigílias e todas as sacras figurações da representação de Deus. Creio que te dás conta do modo pelo qual esses últimos temas demandam mais palavras do que os primeiros: os
} 
da teologia revelados na treva superluminosa do silêncio que ensina ocultamente. Treva que ilumina e "superpleniza com esplendores dos superbens espirituais as inteligências espirituais"". Revelações a que se chega, aconselha Dionísio, quando se deixa de lado "as sensações, as operações intelectuais, todas as coisas sensíveis e inteligíveis, tudo o que não existe e que existe" para unir-se com Aquele que está acima de todo o ser e de todo conhecimento num abandono irrestrito, absoluto e puro. "Visões místicas" são para Dionísio, no entanto, possibilidades dadas a iniciados, a saber, àqueles que não permanecem prisioneiros por supor "nada existir de modo superessencial acima dos seres" e que não "presumem conhecer com a própria sabedoria "Aquele que fez da treva seu esconderijo". ${ }^{10}$

Para ver através da cegueira e da ignorância, e para conhecer o princípio superior à visão e ao conhecimento, explica Dionísio, é preciso ir removendo todas as coisas "do mesmo modo pelo qual aqueles que modelam uma bela estátua aplainam-lhe os impedimentos que poderiam obnubilar a pura visão de sua arcana beleza, sendo capazes de mostrá-la plenamente, mediante remoção". "' À Treva superluminosa, enquanto Causa de tudo, aplicam-selhe todas as afirmações positivas dos seres, todavia, enquanto a tudo transcende, "é mais apropriado negar-Lhe todos os atributos" ${ }^{12}$. As negações, no entanto, não se opõem às afirmações, pois a Causa universal está acima de ambas e é feita "de muitas palavras, de poucas palavras e desprovida de palavras, porque não se Lhe aplica discurso ou pensamento algum"13. A teologia ou teosofia, sabedoria de Deus, conforme indica Dionísio, implica uma dialética ascendente que envolve afirmações e negações que para ele "devem ser louvadas com procedimentos contrários":

Com efeito, afirmamos, quando partimos dos princípios mais originários e descemos através dos membros intermédios às últimas coisas; no caso das negações, todavia, removemos tudo, quando subimos das últimas coisas às mais originárias, para conhecer a ignorância escondida em

\footnotetext{
Esboços teológicos e as explicações dos nomes divinos são mais concisos que a Teologia simbólica. Quanto mais olhamos para cima, mais os discursos se contraem pela contemplação das coisas inteligíveis; assim também, agora, ao penetrarmos na treva superior do intelecto, já não encontramos discursos breves, mas uma total ausência de palavras e de pensamentos". (Dionísio Areopagita, Teologia Mística, p. 25-26)

${ }^{9}$ Cf. Pseudo-Dionísio Areopagita, Teologia Mística, p.15. Usaremos aqui a tradução de Marco Lucchesi.

${ }^{10}$ Ibidem, p. 15-16.

${ }^{11}$ Ibidem, p. 21.

${ }^{12}$ Ibidem, p.16.

${ }^{13}$ Ibidem, p. 17.
} 
todos os seres por todas as coisas cognoscíveis, e para ver a treva supernatural escondida por todas as luzes presentes nos seres. ${ }^{14}$

Segundo Balthasar, para Dionísio, o conhecimento de Deus requer uma penetração sempre mais profunda e o ultrapassamento sempre mais completo da imagem, e as duas coisas não separadas, nem justapostas, mas integrando-se sempre mais profundamente. A teologia é adoração diante da Beleza insondável que aparece em todas as manifestações ${ }^{15}$. Porque Deus é em tudo e além de tudo; a existência e o conhecimento são uma celebração permanente da glória divina que reina em tudo e além de tudo e que se comunica em tudo ${ }^{16}$.

Mística, em Dionísio, segundo esse mesmo autor, é a realização do que Deus, que é Treva mais que luminosa, opera no ser e no conhecer humano que se volta para ele em relação estabelecida por ele. Ela representa uma realização filosófica-teológica do que é: êxtase de si a Deus por imitação do eros extático divino que entra por amor, na multiplicidade do mundo. Êxtase que não será, em Dionísio, perda de identidade, mas fundamento e aprofundamento dela ${ }^{17}$.

A relação da criatura com Deus sempre maior é relação estabelecida por Deus a partir da criação. Nesta relação, cabe a Deus mesmo elevar os véus dissimuladores do ser e do conhecer criados. A impressão negativa disso, que Deus opera, é o método de pensar apofático:

O método de negação contínua e de remoção crescente dos envoltórios simbólicos sensíveis e dos conceitos espirituais não é, para Dionísio, separado da experiência positivamente mística que procede de Deus. O que de concreto ele tem constantemente em vista, não é o método de pensamento, mas é um encontro carregado de experiência, evento que se realiza diante do mistério do Deus vivo apreendido na fé. Por isso, o "terceiro passo", somente mencionado e que ultrapassa a afirmação e a negação, o movimento de ultrapassamento (hyperochê) não é um "método" de conhecimento, mas uma demonstração que além de toda a afirmação e negação de que é capaz a criatura, não há mais que a transcendência absoluta de Deus.

\footnotetext{
${ }^{14}$ Ibidem, p. 21-22.

${ }^{15}$ Cf. Hans Urs VON BALTHAZAR, La Gloire e la Croix: les aspects esthétiques de la Révélation. Paris, Aubier, 155.

${ }^{16}$ Cf. Ibidem, p. 157.

${ }^{17}$ Cf. Ibidem, p. 187.
} 
A palavra suprema da "teologia mística" deve então ser que Deus não é somente além de todas as afirmações, mas também além de todas as negações. ${ }^{18}$

Neste sentido, Deus, que levanta o véu, leva luz àquele que fecha os olhos, transformando o ser e o conhecer; leva à afirmação de que Deus é além de todas as afirmações e negações, Treva mais que luminosa.

Dionísio concorda com autores cristãos antigos, ao acreditar que a alma é divina e pode alcançar uma forma de união indistinta com Deus, mas, em sua visão menos platônica do que a de muitos autores patrísticos, comenta McGinn, entende que ela é divina somente como uma manifestação e é unificada e divinizada somente pelo eros ascendente de Deus. Divinização, neste sentido, é um dom e não um direito de nascença ${ }^{19}$.

A união mística, identificada aqui com a divinização, será, portanto, na concepção de Dionísio, baseada na transcendentalização do conhecimento em não conhecimento e do desejo erótico ${ }^{20}$ em possessão extática. Amor e conhecimento têm papel essencial na ascese amorosa. Para Dionísio, o desejo amoroso (Eros), que é ao mesmo tempo amor caridoso (Aghapé), pode ser entendido como poder para efetuar união, reunião e conservação.

Todavia, dirigindo-se àqueles que sabem entender o verdadeiro sentido das palavras divinas, os santos teólogos, para lhes revelar os segredos divinos, atribuem mesmo valor às duas expressões de caridade e desejo. Com efeito, as duas designam um mesmo poder de unificação e de reunião, e mais ainda de conservação, que pertencem desde de toda eternidade ao Belo-e-Bem graças ao Belo-e-Bem; que emana do Belo-e-Bem; que une uns aos outros os seres da mesma categoria; que leva os superiores a exercer sua providência em relação aos inferiores; que converte os inferiores e os liga aos superiores. ${ }^{21}$

Esse desejo amoroso é capacidade que preexiste em Deus, na Tearquia, e é a partir dela, comunicado à criação, no cósmico pulsar da processão e reversão.

\footnotetext{
${ }^{18}$ Ibidem, p. 188.

${ }^{19}$ Cf. Ibidem, p. 178.

${ }^{20}$ É importante lembrar que Eros deve aqui ser entendido, não a partir de uma perspectiva sexualizada e intersubjetiva, mas como princípio metafísico.

${ }^{21}$ Pseudo-Dionísio, o Areopagita, Os Nomes Divinos, 4.12 (709C-709D), Em: Obras Completas, p. 53.
} 
O desejo amoroso que vem de Deus, em Deus, para nós, é extático. Graças a ele, afirma Dionísio, os amorosos não mais se pertencem, mas pertencem àqueles que amam. É poder de unificação pelo êxtase que é saída de si para o exercício da providência e da comunhão.

\begin{abstract}
(...) O próprio Deus, que é causa universal e cujo desejo amoroso, ao mesmo tempo belo e bom, se estende à totalidade dos seres pela superabundância de sua bondade amorosa, sai também de si mesmo quando exerce suas Providências em relação a todos os seres e que de alguma foram ele os cativa pelo sortilégio de sua bondade, de sua caridade e de seu desejo. É assim que, total e perfeitamente transcendente, não condescende menos ao cuidado de todos os seres graças a este poder extático, supraessencial e indivisível que the pertence. ${ }^{22}$
\end{abstract}

Fundamentalmente, o que Dionísio nos ensina sobre mística é que essa palavra anuncia, por um lado, a inefabilidade, a liberdade e a grandeza da Realidade Última que nos envolve, e, por outro lado, a insuficiência do nosso conhecimento e a inadequação de nossa linguagem incapaz de definições e conceitos que dêem conta de enquadrar essa Realidade. Ele vai nos mostrar que a relação com Deus, absolutamente transcendente, implica o êxtase operado através do procedimento da negação (remoção), com a finalidade última da união transformadora (divinização) pelo amor que é Deus, absolutamente transcendente e totalmente presente em toda a criação. Mística é para ele, qualidade da teologia, um tipo de sabedoria de Deus na qual penetram os iniciados que se dispõem a despojarem-se do próprio saber e abandonando-se de forma irrestrita, absoluta e pura, deixam-se conduzir para o alto e viver n'Aquele que a tudo transcende, unindo-se ao princípio superdesconhecido segundo o melhor (de suas faculdades), mas conhecido além da inteligência ${ }^{23}$.

\title{
3. A mística como experiência subjetiva de Deus
}

É no mundo medieval, entretanto, que uma literatura mística se afirma por si mesma e se desenvolve como busca do divino dentro da alma e como experiência mística de unidade com Deus: "unio mystica", experiência subjetiva que transborda todos os conceitos e doutrinas teológicas. Uma literatura claramente influenciada por Dionísio Areopagita, uma vez que descobre e anuncia que no fundamento de todo o esforço de falar sobre Deus existe uma

\footnotetext{
${ }^{22}$ Ibidem, 4.13 (712A-712B), p.54.

${ }^{23}$ Cf. Pseudo-Dionísio Areopagita, Teologia Mística, p.18.
} 
experiência indizível e que para chegar a Ele é preciso remover, ou como entendem os medievais, exige despojamento de todas as coisas e mais que isso, despojamento de si mesmo, isto é, aniquilamento. A mística medieval vai se expressar num discurso mais voltado para os movimentos provocados na alma, experiência de êxtase (êxodo de si) e transformação pela união com Deus. E aqui talvez possamos falar em mística como "experiência", entendendo esse termo como Congar:

percepção da realidade de Deus vindo até nós, ativo em nós e por nós, atraindo-nos a si numa comunhão, numa amizade, isto é, num ser para o outro. Tudo isso, é claro, aquém da visão, sem abolir a distância na ordem do conhecimento do próprio Deus, mas superando-a no plano de uma presença de Deus em nós como fim amado de nossa vida: presença que se torna sensível através dos sinais nos efeitos de paz, alegria, certeza, consolação, iluminação e tudo aquilo que acompanha o amor. ${ }^{24}$

De Bernardo de Claraval (1091-1153) até Mestre Eckhart (1260-1328) estende-se uma grande corrente de teólogos e especialmente de teólogas, acompanhadas por um verdadeiro movimento popular, que vão falar de Deus absolutamente transcendente a partir da transformação operada por Ele, nelas. Escritos muitas vezes redigidos em primeira pessoa, como testemunho, ou em versos, em forma de canção, e em língua vernácula, como é o Espelho das Almas Simples de Marguerite Porete ${ }^{25}$.

O texto de Marguerite Porete não é fala sobre Deus, ou sobre o humano aberto para Deus, mas é fala da alma com Deus e em Deus. No Espelho das Almas Simples, segundo Luisa Muraro, é possível ouvir as palavras de uma conversação, não apenas nova, mas "inaudita", entre uma mulher e Deus.

Uma mulher estava com certeza, ela diz, Deus não sei, mas com certeza ela não era só, estava um outro ou outra cuja voz não chegava até mim, mas que ouvia o mesmo porque fazia uma interrupção nas palavras dela, ou melhor, uma cavidade que transformava a leitura, a tornava semelhante ao gesto de quem bebe lentamente de uma taça. ${ }^{26}$

\footnotetext{
${ }^{24}$ Yves CONGAR, Revelação e experiência do Espirito, p.13-14.

${ }^{25}$ Cf. Georgette ÉPINEY-BURGARD y Émilie ZUM BRUNN. Mujeres Trovadoras de dios. Una tradición silenciada de la Europa medieval.

${ }^{26}$ Luisa MURARO. Il Dio delle donne, p. 14.
} 
$\mathrm{Na}$ escritura de Marguerite Porete e de outras mulheres desse mesmo período, o absoluto não é o objeto de uma procura, mas é a experiência de uma Presença que desfaz aquele que o está buscando. De posse da pergunta pelo absoluto, reflete ainda Luisa Muraro:

\begin{abstract}
Elas começam da própria experiência e trabalham a tirar do meio e abrir passagens, desfazem sem substituir o mundo desfeito com produtos de pensamento e a escritura delas é um desfazer-se de si (...). Não são construtivas. A pergunta que não desfaz, a procura construtiva, visa a embaraçar assim tanto a mente com os seus objetos e os seus métodos, que não aparece mais uma verdadeira pergunta. Como verdadeira pergunta entendo: uma pergunta cuja resposta não depende de nada que eu tenho e que sou. Uma verdadeira pergunta chama a existência de outra coisa. $^{27}$
\end{abstract}

A experiência religiosa relatada fala de um amor voltado para um objeto inacessível, sempre disposto a perder e nunca seguro de possuir, amor a nada do que se pode imaginar, no entanto, algo real e dotado de poder. Fala da relação com Deus que se faz reconhecer sem nunca se deixar pegar. Nesses textos, a experiência com Deus é descrita como experiência de liberdade que nasce (e isso desafia a compreensão moderna!) do aniquilamento.

A alma aniquilada, afirma Marguerite Porete, apóia-se sobre dois pilares que a faz forte contra seus inimigos, forte como um castelo sobre um monte rodeado pelo mar. Um dos pilares é o conhecimento de sua própria pobreza. O outro é o conhecimento elevado que ela recebe da pura Divindade. De tão tomada pelo conhecimento de sua pobreza, a alma é estranha aos olhos do mundo e aos olhos dos seus. Por outro lado, ela é tão embriagada do conhecimento do amor e da graça da pura Divindade, que está sempre bêbada de conhecimento e repleta de louvores do amor divino. Bêbada não somente do que tem bebido, mas bêbada do que jamais bebeu e do que jamais beberá. Bêbada da bebida que bebe seu bem-amado, pois que, entre ele e ela, por transformação do amor, não há nenhuma diferença. Esta alma é um abismo pela humildade de sua memória, de seu entendimento e de sua vontade, ao mesmo tempo em que é muito livre pelo amor da Divindade.$^{28} \mathrm{~A}$ alma aniquilada, conhecendo sua pobreza, ao mesmo tempo, conhece a bondade de Deus que é a sua salvação. Pois, Deus de bondade não poderia deixar de favorecê-la em sua mendicância, sem se renegar. Tamanha pobreza,

${ }^{27}$ Ibidem, p. 19-20.

${ }^{28}$ Cf. ibidem, p. 85-86. 
entretanto, afirma, não poderia se acomodar com menos do que o cume da abundância de toda a bondade divina.

A salvação, para Marguerite Porete, consiste, portanto, no conhecimento da bondade de Deus a partir do reconhecimento da própria maldade. A autocompreensão da alma como mina de desgraça, explica Babinski, é ao mesmo tempo, o meio pelo qual a alma recebe a divindade. Neste sentido, a humildade torna-se a ocasião para o divino preenchimento. ${ }^{29} \mathrm{E}$ nisso consiste a nobreza, na transformação de amor operada por Deus naquele que se despojou de tudo, até de si mesmo.

$\mathrm{O}$ homem nobre, para a tradição renana, da qual participa Marguerite Porete, é o homem livre, no entanto, não porque nasceu nessa condição, como explica M. Eckhart em seu sermão $O$ homem nobre, mas porque, argumenta ele, inspirado em Agostinho, avança no caminho do desprendimento, degrau a degrau, até o limite que implica despojar-se da própria imagem humana para assumir a imagem divina:

O primeiro degrau é aquele do homem interior e novo, diz Santo Agostinho, consiste em modelar o homem sua vida pelo exemplo de pessoas boas e santas, mas continuando a caminhar pegado às cadeira e cosido às paredes, e a sustentar-se com leite.

$O$ segundo degrau é aquele em que o homem já não olha apenas para os modelos exteriores, inclusive os de homens bons. Mas corre a buscar, pressuroso, a doutrina e o conselho de Deus e da sabedoria divina, dando as costas à humanidade e voltando o rosto para Deus, deixando o regaço da mãe e sorrindo para o pai.

$O$ terceiro degrau consiste em apartar-se o homem mais e mais de sua mãe e em distanciar-se sempre mais de seu colo, fugindo ao cuidado e depondo o temor, de modo tal que, embora pudesse praticar o mal e a injustiça sem dar escândalo a toda a gente, nem assim queria faze-lo; tão íntima é sua união de amor com Deus, e tão zelosa a sua diligência (que não descansa) até que seja introduzido na alegria, na doçura e na bem-aventurança que lhe façam aborrecer tudo que lhe é dessemelhante e alheio.

$O$ quarto degrau consiste em que o homem cresça e se fixe mais e mais no amor e em Deus, dispondo-se assim a enfrentar com vontade e gosto, com sofreguidão e alegria, toda espécie de provação, de tentação, de contrariedade e de padecimento.

\footnotetext{
${ }^{29}$ Ellen BABINSKI, op. cit. p. 6.
} 
O quinto degrau está em que o homem viva em toda a parte na paz interior, descansando tranqüilamente na riqueza e na superabundância da suprema e inefável sabedoria.

O sexto degrau consiste no despojar-se da imagem (humana) e no revestir a imagem da eternidade divina, pelo esquecimento total e perfeito da vida transitória e temporal, de tal modo que, feito filho de Deus, e atraído por Deus, o homem se transmude em imagem de Deus. ${ }^{30}$

É nobre aquele que se despoja de si e nasce do alto. O segredo da nobreza é revelado pelo Filho de Deus.

Com referência a este homem interior e nobre, no qual se encontra impressa e implantada a semente de Deus e a imagem de Deus, e à maneira como se manifesta esta semente e esta imagem da natureza e da essência divina, o Filho de Deus, e como dela se toma conhecimento, e também como por vezes ela se oculta - sobre isso o grande mestre Orígenes apresenta uma comparação: O Filho de Deus, diz, está no fundo da alma como uma fonte viva. ${ }^{31}$

A alma aniquilada é nobre porque, pelo aniquilamento, acolhe a obra de Deus nela. Essa alma que leva a marca de Deus como o lacre toma a forma do selo, afirma Marguerite Porete, sabe que a obra de Deus na criação não é condená-la, mas conformá-la a Ele. ${ }^{32}$ Este é o segredo do Filho que é dado a ela pelo amor do Espírito Santo. A alma aniquilada é, portanto, semelhante à divindade. A liberdade perfeita, que define a nobreza, vem pela graça de Deus que dá à alma o conhecimento do seu nada, conhecimento que leva do mais profundo abismo à mais elevada condição. Em sua nobreza, a oração e a prece da alma, já não pede mais nada, repousa em paz.

Esses teólogos e teólogas vão constituir no interior da teologia cristã medieval, uma tradição ao lado e em controvérsia com a teologia escolástica, mais racional e científica. Mística porque se funda na experiência da alma que procura julgar a realidade com os olhos de Deus e que para isso, considerando a diferença imensa que separa o finito do infinito, deve percorrer um itinerário, atravessar suas próprias faculdades, despojando-se da inteligência e da vontade, confiando que, ao longo desse trabalho, Deus vem a ela e, fazendo aí sua morada, transforma seu saber e seu querer.

\footnotetext{
${ }^{30}$ Mestre ECKHART, A Mistica de Ser e de não Ter, p. 92-93.

${ }^{31}$ Ibidem, p. 93.

${ }^{32}$ Ibidem, p. 115.
} 
Mística é então, nesse contexto, discurso sobre a relação com Deus daquele que faz um percurso que implica o envolvimento num trabalho de despojamento de si, para deixar-se transformar pelo totalmente Outro que, em sua grandeza e liberdade, é absolutamente transcendente, impossível para o entendimento e o querer humanos. Esse processo, em muitos escritos desses que serão posteriormente eles mesmos denominados místicos, é descrito como caminho que conduz a um alto grau de intimidade, experiência de amor que será expressa, como nos poemas de São João da Cruz, através de imagens nupciais ${ }^{33}$ :

Em uma noite escura,

De amor em vivas ânsias inflamada,

Oh! ditosa ventura!

Saí sem ser notada,

Já minha casa estando sossegada.

Na escuridão, segura,

Pela secreta escada, disfarçada,

Oh! ditosa ventura!

Na escuridão velada,

Já minha casa estando sossegada.

Em noite tão ditosa,

E num segredo em que ninguém me via,

Nem eu olhava coisa,

Nem outra luz nem guia

Além da que no coração me ardia.

Essa luz me guiava,

Com mais clareza que a do meio-dia

Aonde me esperava

Quem eu bem conhecia,

Em sítio onde ninguém aparecia.
Oh! noite que me guiaste,

$\mathrm{Oh!}$ noite que juntaste

Amado com amada,

Amada no Amado transformada!

Em meu peito florido

Que, inteiro, para ele só guardava,

Quedou-se adormecido,

$\mathrm{E}$ eu, terna, o regalava,

$\mathrm{E}$ dos cedros o leque o refrescava.

Da ameia brisa amena,

Quando eu os seus cabelos afagava,

Com sua mão serena

Em meu colo soprava,

E meus sentidos todos transportava.

Esquecida, quedei-me,

$\mathrm{O}$ rosto reclinado sobre o Amado;

Tudo cessou. Deixei-me,

Largando meu cuidado

Por entre as açucenas olvidado.

Essas, podemos dizer, são as características fundamentais do que se entendeu como mística ou misticismo, discurso sobre a experiência de Deus que toma impulso nos países do norte entre os séculos XII e XIII, e que floresce também no século XVI na Espanha, e, no século XVII na França. Esse discur-

\footnotetext{
${ }^{33}$ Segundo comentário de São João da Cruz, esses são versos que tratam do modo e maneira que tem a alma no caminho da união de amor com Deus. (Cf. São João da Cruz, Obras Completas, p.439).
} 
so, que recebeu grandes críticas do iluminismo ${ }^{34}$, ganha atualmente renovada atenção pela contribuição que pode dar ao contexto contemporâneo desafiado pelo retorno à preocupação com o sagrado e pela diversidade religiosa.

\section{Mística como experiência subjetiva profunda através e para além da religião}

Não se pode negar que um dos grandes desafios da teologia hoje, mais do que o ateísmo, é o enfrentamento da diversidade religiosa, o obrigatório encontro entre tradições religiosas num mundo globalizado e tenso entre a violência e a promessa de uma frutuosa convivência. Muitas vezes, o impulso para o diálogo representa mais um desejo de assimilação do que verdadeiro respeito à diferença e ao valor da alteridade. Nesse contexto, e em vista do itinerário que fizemos procurando destacar alguns pontos importantes para o entendimento da mística, queremos propor aqui, algumas considerações sobre as contribuições da mesma para a teologia diante do desafio atual do pluralismo religioso:

Em primeiro lugar e fundamentalmente, a mística ensina um grande respeito à verdade abrangente de Deus que é sempre mais do que aquilo que alguém reconhece e percebe, Mistério sempre Absconditus nunca totalmente revelado porque sempre maior do que se pode pensar e até de tudo que se pode desejar. Nesse sentido, a afirmação já presente na tradição mística cristã, expressa na Teologia Mística de Dionísio Areopagita, que Deus é Treva luminosa parece profundamente questionadora de posturas que se arrogam detentoras da totalidade do saber sobre Deus. Para a tradição mística todo conceito positivo sobre Deus, por mais importante que deva ser considerado em sua função

\footnotetext{
${ }^{34}$ Para os modernos, a mística contradiz a ética. Entendida como fé no milagre, isto é, fé em que o humano estaria submetido a uma influência do sobrenatural, a mística levaria necessariamente ao quietismo. Para Kant, na obra "O conflito das faculdades", a mística se refere a uma experiência que não podendo se reduzir à regra da razão, acaba sendo apenas interpretação (aleatória, segundo o nosso entender), de certas sensações, conhecimento interpretativo sem aplicação prática. Para aceitarmos que a transformação do humano em um humano melhor seja fruto de uma experiência mística, afirma Kant,“(...) o homem deveria demonstrar que nele se realizou uma experiência sobrenatural, a qual é em si mesma uma contradição. Poderia, quando muito, admitir-se que o homem teria em si mesmo feito uma experiência (por exemplo, de determinações novas e melhores da vontade), de uma transformação que ele não sabe explicar de outro modo a não ser por milagre, por conseguinte de algo sobrenatural. Mas uma experiência da qual nem sequer se pode convencer que é, de fato, experiência, porque (enquanto sobrenatural) não pode reduzir-se à regra alguma da natureza do nosso entendimento, nem comprovar-se, é uma interpretação de certas sensações, a cujo respeito não se sabe o que com elas se há-de fazer, se terão um objeto efetivo para o conhecimento ou se serão simples devaneios." (Immanuel KANT, O conflito das faculdades, p.70)
} 
de sustentação no caminho para Deus, se relativiza ou se desfaz na medida da aproximação com o Deus vivo absolutamente transcendente.

Em segundo lugar e articulado a esse primeiro ponto, a tradição mística cristã mostra que o mistério de Deus se revela como Amor transformador na intimidade daquele que se dispõe a desprender-se de tudo e até de si mesmo, aquele que sabe reconhecer seu limite, sua fraqueza e sua pobreza. Experimentar Deus supõe, portanto, testemunham os místicos, atravessar e ultrapassar tudo o que serve de mediação no caminho para essa experiência, todos os "nomes transferíveis dos objetos sensíveis às coisas divinas, formas e figuras divinas, partes, instrumentos, lugares divinos, ornatos, iras, aflições, dores, cóleras, ebriedades, excessos, juramentos, imprecações, sonos, vigílias e todas as sacras figurações da representação de Deus" ${ }^{\text {"35 }}$, como mostra Dionísio, e supõe, como ousa afirmar Mestre Eckhart, perder até mesmo a Deus:

Se a alma contempla Deus na qualidade de Deus, enquanto ele é imagem, ou na medida que ele é trinitário, existe nela uma insuficiência. Mas quando todas as imagens da alma são descartadas e ela contempla somente o único Uno, o ser despido da alma descobre o ser despido sem forma da unidade divina que é o ser superessencial que repousa impassível nele mesmo. Ah! Maravilha das maravilhas, que nobre sentimento existe no fato de não poder o ser da alma sofrer outra coisa a não ser a única e pura unidade de Deus! ${ }^{36}$

Essas duas grandes características da experiência de Deus enfatizadas pela mística, a saber, a abertura ao mistério incontível de Deus e a necessidade do despojamento como caminho para o encontro é hoje uma grande contribuição para o estabelecimento de uma postura aberta ao diálogo que sempre esbarra no confronto entre imagens positivas de Deus e definições de caminhos de Salvação. A mística alerta para a fragilidade de todo edifício que se arroga como único caminho para Deus. Afirmando a grandeza e a liberdade infinita de Deus, propõe uma desconfiança crítica de todo caminho positivo para o encontro com Deus e afirma a necessidade do reconhecimento dos limites de toda construção humana que apóia esse caminho. Confia mais na via do despojamento e no potencial da pobreza que promove abertura para a transformação amorosa de Deus do que no poder das instituições e suas indicações dos meios de salvação. A tradição mística convida a não

\footnotetext{
${ }^{35}$ Cf. nota 8 .

${ }^{36}$ Esse trecho do Sermão 83 de Mestre Eckhart está citado em Jean François Malherbe, Sofrer Deus. A pregação de Mestre Eckhart, Aparecida/SP, Editora Santuário, 2006, p. 35.
} 
perder de vista a distinção entre os meios que conduzem a Deus, dispostos no interior das religiões, e a experiência da Presença Dele que transborda todos as limites até mesmo os limites dos quais não escapam as religiões.

Uma terceira característica do discurso místico sobre a experiência de Deus a se destacar diz respeito à ênfase na intimidade de determina a maneira como esse discurso articula singularidade e universalidade. O problema do diálogo muitas vezes está associado ao discurso sobre Deus que procura sempre uma projeção universal. O místico, a mística, ao contrário, não tem como ponto de partida as verdades universais, celebra sua própria experiência, fala em primeira pessoa da sua intimidade com Deus. No entanto, esse mesmo discurso que é particular, ao mesmo tempo, testemunha que o relacionamento com Deus é absolutamente livre, que não se prende a nenhuma determinação de pessoa, de lugar, ou de tradição. A mística revela que o Amor de Deus manifestado na intimidade do sujeito tem abertura universal. A mística ensina, então que, todo edifício construído, toda tradição religiosa, determinada pelas condições limitadas do tempo e do espaço a que pertence, tem no seu fundamento um momento de intimidade com Deus que se manifesta como uma experiência universal, possível para todos, mas que não é posse de ninguém. Daí podemos compreender porque Rudolf Otto vai encontrar na tradição mística, elementos para resgatar a irredutível experiência profunda que ele afirma, encontra-se no fundamento de toda religião, a experiência do numinoso, fenômeno que ele descreve como sendo o princípio vivo de todas as religiões, princípio que "constitui a sua parte mais íntima e, sem ele, não seriam formas da religião" ${ }^{37}$. O encontro com o Numinoso provoca na consciência, ele afirma, o estado de criatura: "o sentimento da criatura que se abisma no seu próprio nada e desaparece perante o que está acima de toda a criatura" ${ }^{38}$, ao mesmo tempo que uma grande bemaventurança:

A criatura que, perante ele treme, se humilha e perde a coragem, experimenta ao mesmo tempo o impulso de se voltar para ele e até dele se apropriar de qualquer maneira. O mistério não é para ela só espantoso, é também o maravilhoso. Ao lado deste elemento perturbador aparece algo que seduz, arrasta, arrebata estranhamente, que cresce em intensidade até produzir o delírio e o inebriamento; é o elemento dionisíaco da ação do numen. ${ }^{39}$

\footnotetext{
${ }^{37}$ Rudolf OTTO, O Sagrado, p.14.

${ }^{38}$ Ibidem, p. 19.

${ }^{39}$ Ibidem, p.50.
} 
O núcleo da experiência religiosa para Otto é a experiência do Sagrado, o Totalmente Outro, Realidade transcendente impossível para a razão ${ }^{40}$ e que promove, como no testemunho dos místicos, temor e fascínio.

A mística, então, agora mais contemporaneamente como mostra a reflexão de Rudolf Otto que não deixa de ser um marco fundamental para a compreensão da experiência religiosa, vai sendo entendida como experiência do Mistério, fenômeno religioso universal que habita a profundidade de todas as formas de religião, isto é, experiência universal que se manifesta particularmente no mais íntimo da subjetividade. Neste sentido, podemos dizer que no interior das tradições religiosas, o Mistério (ao qual se tem acesso através da intuição a respeito da totalidade à qual se pertence, intuição sobre o "estado de criatura") ganha forma no testemunho e, a partir dele torna-se acessível, partilhável até transformar-se em doutrina, formulação. A atenção à experiência mística como experiência de profundidade que fundamenta toda a religião, mas que não coincide necessariamente com sua forma de expressão nas tradições, articula experiência subjetiva e dimensão institucional deixando claro o limite que se encontra em toda a tradição religiosa. A consideração da mística como experiência de Deus na profundidade inefável através, mas também para além dos limites de uma tradição religiosa particular permite ver que toda religião pode ser portadora de revelação divina, e também faz perceber que toda religião tem limites em seu anúncio sobre a relação com Deus.

\section{Mística e Teologia da Revelação: abertura e diálogo}

Essa explicitação da mística como experiência subjetiva, inefável e profunda do mistério de Deus que se dá através, mas além da religião, vem ao encontro também de uma compreensão de revelação com a qual tem se ocupado a teologia atual desde meados do século XX quando começa a ter maior abertura aos desafios modernos e mais disposição ao diálogo. Podemos citar aqui o grande teólogo Karl Rahner, considerado não só um teólogo da mística, mas um místico ${ }^{41}$ e sua confissão de fé no Mistério infinito que fundamenta e que oferece horizonte para todo o conhecimento:

\footnotetext{
${ }^{40} \mathrm{O}$ Totalmente Outro para Otto é inatingível e incompreensível, é "transcendente em relação às nossa categorias", é paradoxal porque não só ultrapassa nossas categorias, mas às vezes, opõe-se a elas, suprimindo-as e confundindo-as e é antinômico porque produz enunciações não só contrárias à razão, às suas leis e normas, mas que não concordam entre si e "que, apesar de referidas ao mesmo objeto, afirmam 'opposita', formando antíteses que parecem inconcebíveis e irredutíveis". (Cf. Rudolf OTTO, op. cit., p.43)

${ }^{41}$ Como nos informa em Herbert Vorgrimler: "Karl Rahner não era apenas um teólogo da mística, ele próprio era um místico. (...) Com Klaus P. Fischer, Nikolaus Schwerdtfeger sublinhou
} 
A mim, (...), me domina e perpassa o Mistério eterno, o Mistério infinito, que é algo "totalmente diferente" [alles andere] de uma espécie de conglomerado em que se vinculam todas aquelas coisas que ainda não conhecemos, nem experimentamos, o Mistério que em sua infinitude e densidade se encontra, ao mesmo tempo, no mais interior e no mais interno das realidades separadas que compõem o que chamamos de "o mundo de nossa experiência". Esse mistério está aí e expressa-se na medida em que se mantém silencioso. Esse Mistério-Secreto deixa que fiquem de lado, serenas [gelassen], as palavras e as explicações, pois falar demais sobre o Mistério transforma-se em palavrório sem sentido [sinnloses Geschwätz]. ${ }^{42}$

Segundo Faustino Teixeira, Rahner exerceu um papel pioneiro na reflexão teológica sobre o valor das outras religiões no desígnio salvífico de Deus, reflexão que se encontra ancorada na sua reflexão antropológica. Para Rahner, explica Faustino, a compreensão do ser humano implica não só a consideração sobre a existência no âmbito da atividade categorial, isto é, no âmbito de sua consciência explícita e objetiva, mas supõe também uma atenção à experiência transcendental, que se caracteriza como experiência de abertura radical, expressão do desejo infinito de transcendência da ordem particular e que reflete a presença de um "mistério santo" que dinamiza a realidade do sujeito em sua busca infinita e que não se traduz, necessariamente em conhecimento explícito ${ }^{43}$. No fundamento compreensão de Rahner de revelação encontra-se também essa experiência do Mistério anunciada na tradição cristã como autocomunicação livre e misericordiosa de Deus que é absolutamente graciosa e, portanto, oferecida de forma universal.

Em atenção à importância da mística, E. Schilebeeckx, por exemplo, vai afirmar um refletir sobre a Revelação divina, levando em conta teologia positiva e teologia negativa, e buscando articular fé, experiência e revelação:

Pelo fato de existir em absoluta liberdade com Deus, ele nos revela que todas as nossas imagens divinas (não a sua

\footnotetext{
que, contrariamente a uma opinião muito difundida, o 'tema fundante' do pensamento de Rahner não foi de tipo filosófico, mas está constituído pela 'experiência mística' da autocomunicação de Deus, que ele descobriu especialmente através da espiritualidade inaciana. Herbert VORGRIMLER, Karl Rahner: experiência de Deus em sua vida e em seu pensamento, p.44-45).

${ }^{42}$ Essa citação de Karl RAHNER encontra-se em Herbert VORGRIMLER, obra citada em nota acima, p.12.

${ }^{43}$ Faustino TEIXEIRA, Karl Rahner e as Religiões, www.iserassessoria.org.br/novo/arqsupload/87.DOC acesso 07/08/2009.
} 
própria realidade) são de fato produtos e projeções humanos que como tais não estão em condições de descrever a realidade divina. Este ponto mais precário de todas as nossas imagens de Deus, não é absolutamente construção ou projeção humana, mas é, ao invés (assim se pode e se deve também interpretar, e assim também se interpreta pelos crentes), uma projeção desde Deus em nossa direção, através de mediações históricas e mundanas. Desde sua realidade mesma, todas as nossas imagens projetivas de Deus são recusadas e desvirtuadas. Neste efeito sobre as nossas imagens de Deus, no esfacelamento contínuo de toda imagem de Deus produzida em nós, revela-se como um alguém ou algo em e em relação para com nossas projeções. ${ }^{44}$

Ao orarmos ao Deus vivo, como faz o místico, usamos nossas imagens (como mediação) que são ao mesmo tempo esfaceladas na própria oração.

Ao orarmos ao Deus real e vivo, temos diante dos olhos apenas "imagens de Deus" que são esfaceladas na própria oração pelo referente "real" ao qual rezamos. (...) O referente "real" do nome de Deus não deve, portanto, confundir com nossos objetos de experiência e tampouco com nossas construções e projeções, que, não obstante, desempenham algum papel em toda fé em Deus.

A experiência do encontro imediato com Deus provoca a visão de uma possibilidade nova, radicalmente diferente do que foi e do que é. Caem por terra as velhas imagens de mundo e de si mesmo. As velhas palavras já não servem para expressar a nova experiência, ocorre, em resumo, ruptura e vivência de algo inusitado.

Algo de transcendente e ao mesmo tempo abrangente de tudo; origem tanto de toda objetividade como de toda subjetividade. Uma experiência salvífica incondicionada, experiência também de totalidade e de reconciliação... não obstante constatação de sofrimento e não-reconciliação.

É com base nessa mesma perspectiva de revelação ${ }^{45}$ que Queiruga vai tecer sua teologia fundamental enfatizando a abertura ao diálogo entre as

\footnotetext{
${ }^{44}$ Edward SCHILLEBEECKX, História humana, revelação de Deus, São Paulo, Paulus, 1994, p.105.

${ }^{45}$ Mesmo que Queiruga não explicite como os dois outros autores citados o tema da mística, não podemos negar que a sua teologia fundamental tem um vinculo muito estreito com esses autores.
} 
religiões, afirmando que "Deus fala a todos", e que luta para oferecer-se à humanidade, para superar os obstáculos que se interpõem ao encontro, que são por um lado, o limite, a finitude a relatividade, os determinismos de que sofre a condição humana e, por outro lado, o fechamento, o egocentrismo, a acomodação fruto da opção humana:

Deus, voltado com todo o seu amor sobre a humanidade, luta contra nossa ignorância e nossa pequenez, contra nossos instintos e resistências, contra nossos malentendidos e perversões, para ir abrindo-nos seu coração e iluminar para nós seu rosto, para manifestar-nos a profundidade de nosso ser e a esperança de nosso destino. ${ }^{46}$

No contexto dessa concepção de revelação, ele afirma, todas as religiões são verdadeiras:

Qualquer avanço em um ponto representa, definitivamente, uma vantagem para os demais. Por essência, toda revelação concreta tem por vocação chegar a todos, jamais permanecendo como propriedade exclusiva daquele que alcança; no momento mesmo de ser captada por alguém, já pertence, por direito, à humanidade. (...) Daí a enorme importância do diálogo entre as religiões. ${ }^{47}$

Aí podemos ver a importante contribuição da mística para a teologia, em sua oferta de elementos para uma melhor compreensão da revelação capaz de dar suporte para se lidar com a tensão entre absolutez e relatividade existente nas religiões em diálogo contra os riscos de diante da diferença, se sucumbir no fundamentalismo ou no relativismo que promovem a violência. E para concluir podemos dizer que a atenção à mística certamente tem trazido e se bem compreendida, continuará trazendo condições de se realizar, através da religião e para além dela, a almejada promessa de frutuosa convivência.

\section{Résumé}

La relation de la Théologie avec la mystique n'a pas toujours été aussi étroite et proche qu'il devrait être. La proposition de cet article est montrer combien est importante la mystique dans la théologie et pour percevoir que dans les différentes conceptions théologiques peuvent, beaucoup de fois,

\footnotetext{
${ }^{46}$ QUEIRUGA, Andrés Torres. Do Terror de Isaac ao Abbá de Jesus, p.34

${ }^{47}$ Ibidem, p.35-36.
} 
conduire à des ruptures et à des divergences. Dans ce cas, la mystique favorise un surpassement de paradigmes théologiques fermé.

\author{
Ceci Baptista Mariani \\ $\mathrm{EDT} /$ ITESP / PUCCAMP
}

\title{
Bibliografia
}

BABINSKI, Ellen, Christological transformation in The Mirror of Souls, by Marguerite Porete, Theology Today, abril de 2003.

BAPTISTA MARIANI, Ceci Maria Costa. Marguerite Porete, teóloga do século XIII. Experiência mística e teologia dogmática em $O$ Espelho das Almas Simples de Marguerite Porete. Tese de doutorado. São Paulo, Pontifícia Universidade Católica de São Paulo, 2008.

BOUYER, L. . "MYSTIQUE” Essai sur l'histoire dúm mot. La Vie Spirituali, no.9 - 15 Mai 1949.

CONGAR, Yves. Revelação e experiência do Espírito, São Paulo, Editora Paulinas, 2005.

MESTRE ECKHART, A Mística de Ser e de não Ter, Petrópolis, vozes, 1983.

ÉPINEY-BURGARD, Georgette y ZUM BRUNN, Émilie. Mujeres Trovadoras de dios. Una tradición silenciada de la Europa medieval, Barcelona, Ediciones Paidós, 2007.

GARI, Blanca. El camino al "País de la libertad" en El espejo de las almas simples. DUODA Revista d'estudis Feministes, 9 (1995), p.49-68. . Mirarse en el espejo: difusión y recepción de un texto, DUODA Revista d'estudis Feministes, 9 (1995), p.99-117.

SÃO JOÃO DA CRUZ, Obras Completas, Petrópolis/SP, Vozes, 2000.

KANT, Immanuel. O conflito das faculdades, Lisboa, Edições 70,

MALHERBE, Jean François. Sofrer Deus. A pregação de Mestre Eckhart, Aparecida/SP, Editora Santuário, 2006, p. 35.

McGINN, Bernard. The Foundations of Mysticis : The Presence of God: A History of Western Christian Mysticism. New York, Crossroad, 2003,

MURARO, Luisa, Il Dio delle donne, Milano, Mondadori, 2003.

OTTO, Rudolf, O Sagrado. Lisboa, Edições 70, s/d.

PORETE, Marguerite. Le Miroir des âmes simples et anéanties, introdução, tradução ao francês moderno e notas por M. Huot de Longchamp, Albin Michel, Paris, 1984. 
PSEUDO-DIONÍSIO, O AREOPAGITA, Os Nomes Divinos, 4.12 (709C709D), Em: Obras Completas, São Paulo, Paulus, 2004. Teologia Mística. Rio de Janeiro, Ed. Fissus, 2005.

QUEIRUGA, Andrés Torres. Do Terror de Isaac ao Abbá de Jesus. São Paulo, Ed. Paulinas, 2001.

SCHILLEBEECKX, Edward. História humana, revelação de Deus, São Paulo, Paulus, 1994.

SELL Carlos Eduardo e BRüSEKE, Franz Josef. Mistica e Sociedade. Itajaí, Universidade do Vale do Itajaí, São Paulo, Editora Paulinas, 2006.

SUDBRACK, Josef. Mística, a busca do sentido e a experiência do absoluto. São Paulo, Loyola, 2007.

TEIXEIRA Faustino, Karl Rahner e as Religiões.

VON BALTHAZAR, Hans Urs. La Gloire e la Croix: les aspects esthétiques de la Révélation. Paris, Aubier.

VANNINI, Marco. Introdução à Mística, São Paulo, Loyola, 2005.

WILDERINK, Ocarm. Vital J. G.. Mistica e Místicos, Belo Horizonte, Ed. Divina Misericórdia, 2004. 